\title{
Factors of predicting the acceptance of the COVID-19 vaccine in West Africa (a cross-sectional study in Nigeria)
}

1 Adeleke O.R.

1 Adegboro J.S.

1 Olofintuyi 0.0.

1 Ayenigbara I.O.

1 Aina S.I.

1 Fadero E.O.

1 Oluwadare R.S.

1 Olaseyo T.

1 Department of Human Kinetics and Health Education, Adekunle Ajasin University, Akungba-Akoko

\section{Abstract}

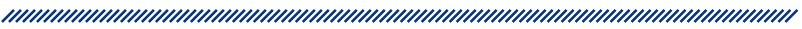

Background: The aim of this study was to examine the factors predicting the acceptance of COVID-19 vaccines in West Africa, with a focus on Nigeria. Four (4) hypotheses were posed for this study.

Methods: This study employed a descriptive method design. The sample size was comprised of 32,224 respondents, all Nigeria citizens. A multistage sampling technique was employed for the survey involving quantitative data. A questionnaire was used as the instrument for data collection. The data collected for this study were analysed using both descriptive and inferential statistics (t-test and ANOVA).

Results: The findings of this study revealed that there is a significant difference in COVID-19 vaccine acceptance based on age $F(9,32214)=812.114, P<0.05, \eta^{2}=0.1849$; based on gender differences $t=(32222)=-21.808$, $\mathrm{P}<0.05$; based on religion $\mathrm{t}=(32222)=--75.228, \mathrm{P}<0.05$; and based on income $F(4,32219)=740.394, P<0.05$, $\eta^{2}=0.084$.

Conclusion: The findings of this study show that there is a significant relationship between age, gender, religion, income and the acceptance of COVID-19 vaccines in $\mathrm{Ni}$ geria. The findings further show that men are more vaccine-hesitant than women; older people find it easier to accept vaccination; Christians are more likely to accept COVID-19 vaccines than people from other religions. It is therefore recommended that religious leaders should be well educated on the health benefit of the COVID-19 vaccination and that the government should put more effort into improving the economy of the country so that the individual income can improve.

Keywords: acceptance, COVID-19, pandemic, predicting factors, vaccination

Article received: 16.5 .2021 .

Article accepted: 1.11.2021.

https://doi.org/10.24141/1/8/1/1

Corresponding author:

Adeleke O.R.

A: Department of Human Kinetics and Health Education, Adekunle Ajasin University, Akungba-Akoko, Ondo State, Nigeria E-mail: olasunkanmi.adeleke@aaua.edu.ng 


\section{Introduction}

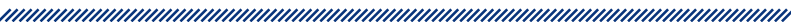

Currently, the world is affected by the COVID-19 pandemic, which has been a public health challenge of international concern since February, 2020 (1). The coronavirus disease 2019 (COVID-19) pandemic has imposed a heavy burden on the world, and there are currently no specific antiviral treatments for COVID-19, although numerous probable drug candidates and treatment options are currently undergoing experimental stages globally (2-4). World-wide fear and anxiety still exist among different populations about contracting the virus. For example, a study conducted in March 2020 in the US during the initial outbreak of COVID-19 found that $25 \%$ of people were very worried about contracting the virus, with around $13 \%$ not worried at all, while those who rated the virus as less serious were younger, male, with lower income, and black (5).

Over the years, and through the advancement in medical sciences, vaccines have saved and prevented many lives from various diseases and infections. Vaccines mostly work by training and preparing the body's natural defences, i.e., the body's immune system, to acknowledge and fight against targeted pathogens so that when the body is exposed to those disease-causing germs later, the body is instantly able to destroy them, thereby preventing potential threats of diseases (6). To bring the COVID-19 pandemic to an end or control the rate of its infection, a substantial number of the world's population must be resistant to the virus, and the safest and most viable means to achieving this is through global vaccination.

Immunization is one of the most successful and cost-effective health interventions which humanity has often relied on in the past to prevent infectious diseases and reduce the number of deaths, and vaccination against COVID-19 will be of great importance in the prevention and control of the pandemic $(7,8)$. In an effort to achieve that, within a year after the onset of the COVID-19 pandemic, several researchers around the world worked to develop vaccines that offer significant levels of protection against SARS-CoV-2, the virus that causes COVID-19 (9).

In recent times there have been numerous studies on vaccination uptake and vaccine acceptance for various diseases and infections based on human behaviour. While evidence on promoting vaccination is generally beneficial within the purview of the current pandemic, the acceptance and uptake of the COVID-19 vaccines has presented an unprecedented challenge for medical practitioners and political leaders globally. This is the result of the methods of vaccination, the urgency of the production of vaccines, the novel nature of the vaccines, and the unspecified duration of the effectiveness of the vaccines. Although the behavioural goal is the uptake of COVID-19 vaccine by the whole population, achieving that goal will depend on the behaviours of those administering the inoculations, those planning how and where to supply the vaccination, and people tasked with maximizing uptake using strategies like persuasion and therefore the use of trusted endorsers (or "validators"). Sometimes, barriers to vaccine acceptance and uptake are the causes of unfavourable social influences and/or insufficiently favourable ones. Such influences can include beliefs about what others in one's social group do or what they approve and disapprove of ("social norms") (10). Also, vaccination decision-making is also influenced by people's social networks, which include family members, friends, health professionals and others with whom they interact, as well as their background characteristics.

The age of an individual can be a determining factor in accepting a vaccine. Because the majority of literature on vaccination is on childhood vaccination, the impact of age varies according to whether it is a vaccine aimed at children or adults (11). Age patterns generally show that younger people are less likely to be vaccine hesitant, particularly in relation to vaccinations for children and young adults (12). In the case of seasonal influenza and pandemic vaccination, existing literature shows that the elderly have more tendency to receive vaccination. Given that recent pandemics (such as H1N1) and seasonal influenza are more detrimental to the older population (13), these differences are logical. A systematic review of $\mathrm{H} 1 \mathrm{~N} 1$ vaccination uptake found that those who had higher intentions of receiving vaccination were likely to be older, which is related to the agerelated risks of that virus (14).

Gender is another factor that can determine whether a person will accept a vaccine or not. Men are more likely to hold anti-vaccine sentiments than women (12), which is striking given that many of the anti-vaccine MMR parental activists and online forums are populated by women. Studies of H1N1 found, however, that men had higher intentions of receiving vaccination than women (14). In addition, the parental factor based on 
attitudes and behaviours may contribute to vaccine acceptance. Given that the majority of the literature has focused on children's vaccinations and parental attitudes, studies often report the attitudes of mothers and fathers as opposed to parents in general (15). According to one researcher, Jennifer Reich, who studied vaccination hesitancy of parents in relation to measles, exploring what defines good parenting in relation to vaccination, relatively few parents actually reject vaccines, but instead harbour concerns about children's safety and the pain of injections, which suggests the need for dialogue and communication in order to understand these concerns (16).

The religion one practices is another sensitive component to consider in terms of accepting vaccination because many who are religious fanatics may refuse to accept that a vaccine protects them against diseases. Religious people adhere to the instructions of their leaders; therefore, the clarity of messages surrounding the safety of the vaccines should also be sensitive and address concerns across religious and cultural groups. For example, the drop in confidence in vaccines in Indonesia has been partially linked to key Muslim leaders who questioned the safety of the MMR vaccine and issued a fatwa (religious ruling) that the vaccine was haram (i.e. containing ingredients derived from pigs, thus unacceptable to Muslims) (17). In addition, a predominantly Muslim sample of respondents in Malaysia reported concerns that the vaccine was not a halal vaccine, leading to those respondents being less likely to accept vaccination (18).

The coronavirus disease 2019 (COVID19) pandemic has spread and continues to spread across the planet with millions infected and many thousands dead $(19,20)$. The information available from Our World in Data (2021) as of $17^{\text {th }}$ January 2021 shows that Israel, the UK, the UAE, the US, Denmark, Bahrain, Slovenia, Italy, Spain, Ireland, Germany, Saudi Arabia, Turkey, Russia, France, Mexico, and Argentina have commenced the vaccination procedure and started its administration. In contrast, while most affected countries have developed successful response strategies and observed significant improvements, such as developing a COVID-19 vaccine, there is less emphasis on whether this vaccine might be accepted in other countries of the world (21). Despite the known benefits of vaccines all over the world and their effectiveness in preventing targeted diseases, populations in some West African countries have refused to accept the COVID-19 vaccines on the basis of some allegations and socio-demographic factors, and
Nigeria is no exception. It is on this basis that this study is designed to examine the factors predicting the acceptance of the COVID-19 vaccine in West Africa, with a focus on Nigeria.

\section{Research question}

Is there a significant relationship between age, gender, religion, and the income status of Nigerians and the acceptance of a COVID-19 vaccine?

Research hypotheses

1. There is no significant difference between the acceptance of COVID-19 vaccine and age.

2. There is no significant difference between the acceptance of COVID-19 vaccine and gender.

3. There is no significant difference between the acceptance of COVID-19 vaccine and religion.

4. There is no significant difference between the acceptance of COVID-19 vaccine and income.

\section{Methodology}

This study employed a descriptive method design and used concurrent explanatory methods of quantitative approaches. The study population was comprised of Nigerian citizens who reside in the county. The list of states with different ethnic groups selected across the geopolitical zones was obtained as the sampling frame from which the sample size was drawn for this study. The sample was comprised of 32,224 respondents. A multistage sampling technique was employed for the survey involving quantitative data. The first stage involved stratified sampling of the states according to major ethnic groups in Nigeria. Simple random sampling was used to select respondents from each ethnic group based on their population percentage (\%) in the country as the second stage. They include Hausa $29 \%$, Fulani $26 \%$, Yoruba $21 \%$, Igbo $18 \%$, ljaw $10 \%$, Kanuri $4 \%$, Ibibio $3.5 \%$ and Tiv $2.5 \%$ of the total population, from which $0.2 \%$ of the population was selected. This means that 10,851 of the respondents were Hausas, 8,062 Fulanis, 7,281 Yorubas, 3,087 Igbos, 1,045 ljaws, 928 Kanuris, 592 Ibibio and 378 Tivs. The third stage involved the use of the purposive sampling technique to administer the instrument to the selected study re- 
spondents. A questionnaire was used as the instrument for data collection. The data collected for this study were analysed using both descriptive and inferential statistics. Quantitative data collected through questionnaire were analysed using inferential statistics for the t-test and ANOVA.

\section{Results}

\begin{tabular}{|c|c|c|}
\hline Variables & Frequency & Percentage \\
\hline Age & & \\
\hline Less than 18 years & 546 & 1.7 \\
\hline $18-24$ & 5,492 & 17.0 \\
\hline $25-31$ & 12,352 & 38.3 \\
\hline $32-38$ & 5,894 & 18.3 \\
\hline $39-45$ & 2,199 & 6.8 \\
\hline $46-52$ & 2,800 & 8.7 \\
\hline $53-59$ & 1,596 & 5.0 \\
\hline $60-66$ & 504 & 1.6 \\
\hline $67-73$ & 420 & 1.3 \\
\hline 74 and above & 421 & 1.3 \\
\hline \multicolumn{3}{|l|}{ Gender } \\
\hline Male & 13,116 & 40.7 \\
\hline Female & 19,108 & 59.3 \\
\hline \multicolumn{3}{|l|}{ Religion } \\
\hline Islam & 21,735 & 67.4 \\
\hline Christian & 10,489 & 32.6 \\
\hline Traditional & 0 & 0 \\
\hline Others & 0 & 0 \\
\hline \multicolumn{3}{|l|}{ Income } \\
\hline$<50,000$ & 16,767 & 52.0 \\
\hline $51,000-100,000$ & 6,623 & 20.6 \\
\hline $101,000-200,000$ & 4,831 & 15.0 \\
\hline $201,000-500,000$ & 3,491 & 10.8 \\
\hline 501,000 and above & 512 & 1.6 \\
\hline Total & 32,224 & 100.0 \\
\hline
\end{tabular}




\begin{tabular}{|c|c|c|c|c|c|c|c|c|c|}
\hline \multirow[b]{2}{*}{ Age } & \multirow[b]{2}{*}{$\mathrm{N}$} & \multirow[b]{2}{*}{ Mean } & \multicolumn{4}{|c|}{ COVID-19 vaccine acceptance } & & & \\
\hline & & & $\begin{array}{c}\text { Std. } \\
\text { deviation }\end{array}$ & & $\begin{array}{l}\text { Sum of } \\
\text { squares }\end{array}$ & df & $\begin{array}{l}\text { Mean } \\
\text { square }\end{array}$ & $\mathrm{F}$ & Sig. \\
\hline less than 18 years & 546 & 2.8551 & .85304 & & & & & & \\
\hline $18-24$ & 5,492 & 3.0731 & .90413 & & & & & & \\
\hline $25-31$ & 12,352 & 3.3220 & .94196 & Between groups & 6757.998 & 9 & 750.889 & 812.114 & .000 \\
\hline $32-38$ & 5,894 & 3.5476 & .94014 & Within groups & 29785.376 & 32214 & .925 & & \\
\hline $39-45$ & 2,199 & 3.8228 & .99913 & Total & 36543.374 & 32223 & & & \\
\hline $46-52$ & 2,800 & 4.1027 & 1.03705 & & & & & & \\
\hline $53-59$ & 1,596 & 4.3551 & 1.05918 & & & & & & \\
\hline $60-66$ & 504 & 4.6894 & 1.09524 & & & & & & \\
\hline $67-73$ & 420 & 4.9240 & 1.11326 & & & & & & \\
\hline 74 and above & 421 & 5.1754 & 1.21120 & & & & & & \\
\hline Total & 32,224 & 3.5326 & 1.06493 & & & & & & \\
\hline
\end{tabular}

Table 2 shows that there is a significant difference in COVID-19 vaccine acceptance based on age; $F(9,32214)=$ $812.114, P<0.05, \eta^{2}=0.1849$. Thus, the first hypothesis is rejected.

\begin{tabular}{|c|c|c|c|c|c|c|c|}
\hline \multicolumn{7}{|c|}{$\begin{array}{l}\text { Table 3. T-test summary showing the difference between } \\
\text { COVID-19 vaccine acceptance and gender }\end{array}$} \\
\hline Variable & Gender & $\mathrm{N}$ & Mean & Std. dev. & T & d.f & Sig. \\
\hline $\begin{array}{c}\text { CovID-19 vaccine } \\
\text { acceptance }\end{array}$ & Male & 13,116 & 3.3785 & 1.03657 & & & \\
\hline
\end{tabular}

Table 3 shows that there is a significant difference in the acceptance of the COVID-19 vaccine between men and women; $\mathrm{t}=(32222)=-21.808, \mathrm{P}<0.05$. Thus, the second hypothesis is rejected.

\begin{tabular}{|c|c|c|c|c|c|c|c|}
\hline \multicolumn{6}{|c|}{ Table 4. T-test summary showing the difference between COVID-19 vaccine acceptance and } \\
religion
\end{tabular}

Table 4 shows that there is a significant difference in the acceptance of the COVID-19 vaccine based on religion; $t=(32222)=--75.228, P<0.05$. Thus, the third hypothesis is rejected. 


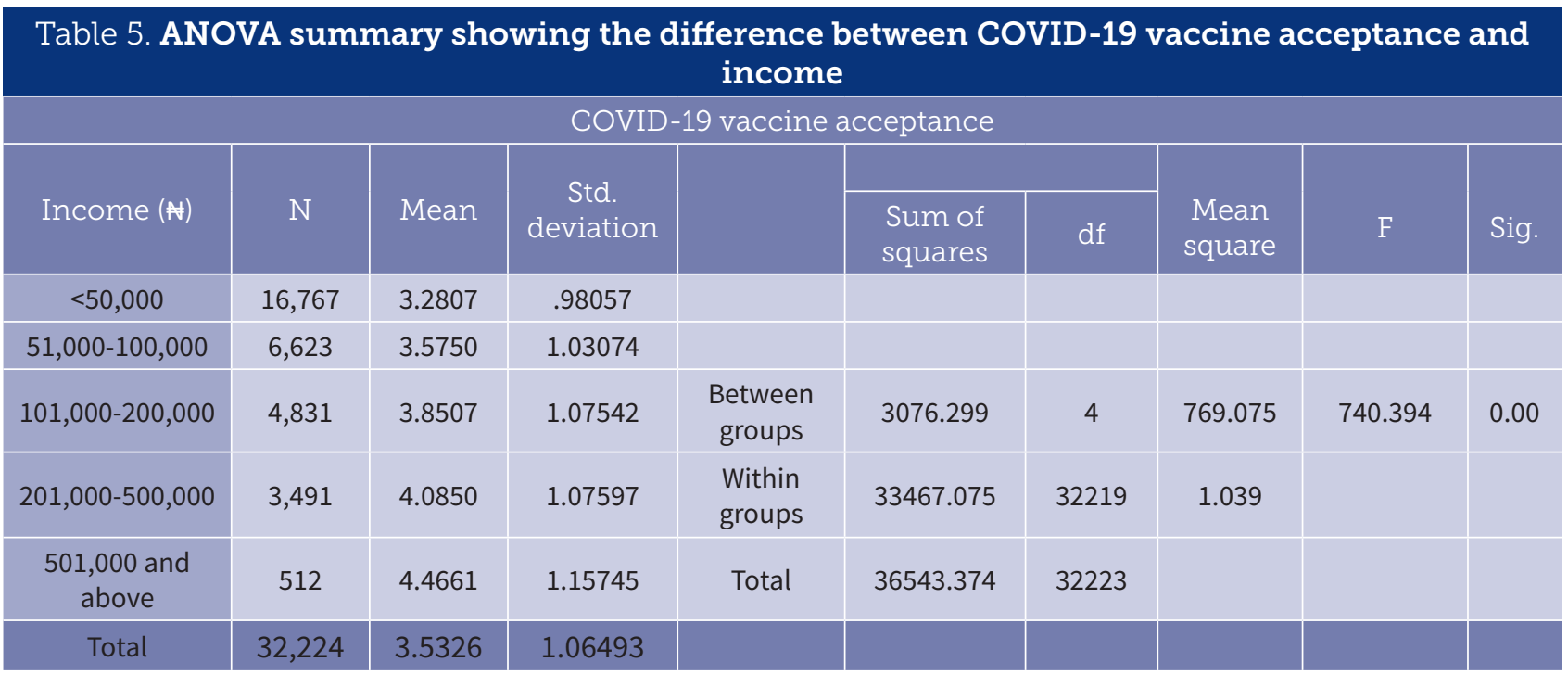

Table 5 shows that there is a significant difference in COVID-19 vaccine acceptance based on the income level of the respondents; $F(4,32219)=740.394, P<0.05, \eta^{2}=0.084$. Thus, the fourth hypothesis is rejected.

\section{Discussion}

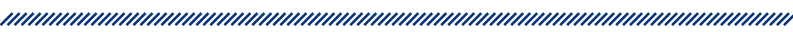

This study provides a detailed characteristic of Nigerians of different religion, income level, age, and gender who served as study respondents. Table 1 shows the background attributes based on age, gender, ethnicity, religion, the educational level, and the socioeconomic status of the respondents. 12,352 (38.3\%) of the respondents fall within 25-31 years of age bracket, while $420(1.3 \%)$ fall within the bracket of $67-73$ years of age. Based on gender, the majority of the respondents, 19,108 (59.3\%), were female, while 13,116 (40.7\%) were male. Out of 32,224 respondents, 21,735 (67.4\%) were Muslims, while 10,489 (32.6\%) were Christians. 10,851 (33.7\%) of the respondents were Hausas, while a small portion of the respondents were Ibibios. Also, 14,946 $(46.4 \%)$ of them had no formal education, while 3,399 $(10.5 \%)$ were primary school leavers. Based on the level of income, a large number of the respondents (52\%) earn less than 50,000 naira per month, while 512 (1.6\%) earned more than 500,000 naira.

The age of an individual has a significant connection with COVID-19 vaccine acceptance. Table 2 shows that people aged 74 and above displayed the highest ten- dency to accept the COVID-19 vaccine (mean $=5.175$ ), followed by those in the 60-66 age group (mean=4.689), while young people of less than 18 years of age (mean=2.8551) displayed the lowest tendency to accept the COVID-19 vaccine, followed by those within the age bracket of 18-24years of age (mean=3.0731). This finding is similar to the results of (11), showing that the impact of age varies according to whether it is a vaccine aimed at children or adults. However, age patterns generally show that younger people are less likely to be vaccine-hesitant, particularly in relation to vaccinations for children and young adults (12). A systematic review conducted by (14) of $\mathrm{H} 1 \mathrm{~N} 1$ vaccination uptake found that those who had higher intentions for vaccination were likely to be older, which was connected with the age-related risks of that virus.

The findings of this study revealed that the gender difference can play a role in a person's decision to accept the vaccine. Table 3 shows that women (mean=3.6384) have a higher tendency to accept the COVID-19 vaccine than their male counterparts (mean=3.3785). This result is supported by the study of (12), which showed that men are more likely to hold anti-vaccine sentiments than women, which is striking given that many of the anti-vaccine MMR parental activists and online forums are populated by women. However, on the contrary, one study of H1N1 (14) found that men had higher 
intentions of vaccination than women, which may be a result of the study being a systematic review. Even more importantly, the study review was conducted in a developed country.

Table 4 shows that Christians (mean $=4.1520$ ) have a higher tendency to accept the COVID-19 vaccine than Muslims (mean=3.2337). One study (18) found that a Muslim sample of respondents in Malaysia reported concerns that the vaccine was not a halal vaccine, leading to the respondents to be less likely to be vaccinated.

Notably, information available online has been found to have a stronger impact on the biases of college-educated mothers than newspaper coverage, with exposure to negative information strengthening their bias via the mechanism of confirmation bias in relation to education and socio-economic status, with those of lower income and the unemployed holding less positive views of vaccines (15).

Table 5 shows that people who earn more than $\$ 500,000$ displayed the highest tendency of accepting the COVID-19 vaccine (mean $=4.4661)$, followed by those who earn between $\# 201,000$ and $\# 500,000$ (mean=4.0850), while those who earn less than $\$ 50,000$ (mean $=3.2807$ ) have the lowest tendency of accepting the COVID-19 vaccine.

\section{Conclusion}

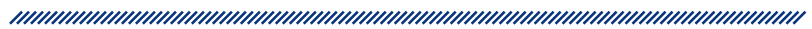

The findings of this study concluded that there was a significant relationship between age, gender, religion, income, and the acceptance of the COVID-19 vaccine in Nigeria. The findings also showed that men are more vaccine-hesitant than women, while older people find it easier to accept vaccination; Christians are more likely to accept the COVID-19 vaccine than people from other religions.

\section{Recommendations}

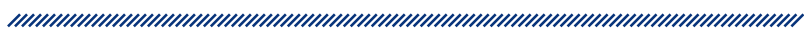

The following recommendations were made:

- Health education on the benefits of the COVID-19 vaccine should be intensified at all levels of education so that young people can make informed decisions about vaccination.

- Specific health education should be designed to focus on gender so as to reduce the anti-vaccination tendency.

- Religious leaders should be well educated on the health benefit of COVID-19 vaccination.

The government should invest more effort into improving the economy of the country so that the individual income can improve.

\section{Acknowledgement}

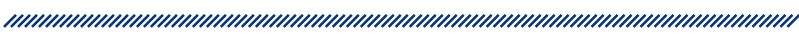

We thank our dear professor G.O. Ayenigbara for the role he played in the editing of this work.

Conflict of interest: None

Funding: None 


\section{References}

1. Ayenigbara, I.O. COVID-19: an international public health concern. Cent Asian J Glob Health. 2020;9:1-11. doi: 10.5195/cajgh.2020.466.

2. Huang, C., Wang, Y., Li, X., Ren, L., Zhao, J., Hu, Y., Zhang, L., Fan, G., Xu, J., Gu, X. (2020). Clinical features of patients infected with 2019 novel coronavirus in Wuhan, China. Lancet 2020, 395, 497-506. (CrossRef)

3. Ayenigbara, I.O., Adeleke, O.R., Ayenigbara, G.O., Adegboro, J. S. and Olofintuyi, O.O. 2020. COVID-19 (SARS-CoV-2) pandemic: Fears, facts and preventive measures. Germs 10 (3):218-28.doi:10.18683/germs.2020.1208

4. World Health Organization. (2020). SAGE values framework for the allocation and prioritization of COVID-19 vaccination, 14 September 2020. Geneva: World Health Organization; 2020 (https://apps.who.int/iris/handle/10665/334299, accessed 18 November 2020).

5. Wolf, M.S. (2020). Awareness, Attitudes, and Actions Related to COVID-19 Among Adults With Chronic Conditions at the Onset of the U.S. Outbreak. Annals of Internal Medicine 173, 100 - 109. (doi:10.7326/m20-1239)

6. World Health Organization. (2021) Coronavirus disease (COVID-19) advice for the public (website). Geneva:(https://www.who.int/emergencies/diseases/ novel-coronavirus-2019/advicefor-public, accessed 9th January, 2021).

7. Lurie, N., Saville, M., Hatchett, R., Halton, J. (2020). Developing Covid-19 Vaccines at Pandemic Speed. N . Engl. J. Med. 2020, 382, 1969-1973. (CrossRef)

8. Yang, Peng, Wang, Guan, Jiang, Xu, Sun, Chang. (2020). Clinical Pathway for Early Diagnosis of COVID-19: Updates from Experience to Evidence-Based Practice. Clinic Rev Allerg Immunol 59, 89-100 (2020). https://doi. org/10.1007/s12016-020-08792-8

9. Ritchie, H., Ortiz-Ospina, E., Beltekian, D., Mathieu, E., Hasell, J., Macdonald, B., Giattino, C. and Roser, M. (2021). Coronavirus (COVID-19) Vaccinations. Our World In Data (Charity Number 1186433). Available at https:// ourworldindata.org/covid-vaccinations

10. Cialdini, R. B., Demaine, L. J., Sagarin, B. J., Barrett, D. W., Rhoads, K., Winter, P. L. (2006). Managing Social Norms for Persuasive Impact. Social Influence. 1:3-15. doi:10.1080/15534510500181459.

11. Lovari, A., Martino, V., Righetti, N. (2020) Blurred Shots: Investigating the Information Crisis Around Vaccination in Italy. American Behavioral Scientist, 000276422091024. (doi:10.1177/0002764220910245)
12. Larson, H. J, Jarrett, C., Eckersberger, E., Smith, D. M., Paterson, P. (2014) Understanding vaccine hesitancy around vaccines and vaccination from a global perspective: A systematic review of published literature, 2007 - 2012. Vaccine 32, 2150 - 2159. (doi:10.1016/j.vaccine.2014.01.081)

13. Dowd, J.B., Andriano, L., Brazel, D.M., Rotondi, V., Block, P., Ding, X., Liu, Y., Mills, M.C. (2020) Demographic science aids in understanding the spread and fatality rates of COVID-19. Proc Natl Acad Sci USA 117, 9696 - 9698. (doi:10.1073/pnas.2004911117)

14. Bish, A, Yardley, L, Nicoll, A, Michie, S. (2011). Factors associated with uptake of vaccination against pandemic influenza: A systematic review. Vaccine 29, 6472 - 6484. (doi:10.1016/j.vaccine.2011.06.107)

15. Qian, M., Chou, S.Y, Lai, E.K. (2020). Confirmatory bias in health decisions: Evidence from the MMR-autism controversy. Journal of Health Economics 70, 102284. (doi:10.1016/j.jhealeco.2019.102284)

16. Reich, J.A. (2016). Calling the Shots: Why Parents Reject Vaccines. New York University Press; 2016

17. Yufika, A. (2020) Parents' hesitancy towards vaccination in Indonesia: A cross-sectional study in Indonesia. Vaccine 38, 2592 - 2599. (doi:10.1016/j.vaccine.2020.01.072)

18. Wong LP, Sam I-C. 2010 Factors influencing the uptake of $2009 \mathrm{H} 1 \mathrm{~N} 1$ influenza vaccine in a multiethnic Asian population. Vaccine 28, 4499 - 4505. (doi:10.1016/j.vaccine.2010.04.043)

19. Dong, E., Du, H., Gardner, L. (2020). An interactive webbased dashboard to track COVID-19 in real time. Lancet Infect Dis 2020;20(5):533-4.

20. Johns Hopkins University and Medicine. (2020). Coronavirus resource center: COVID-19 dashboard by the center for systems science and engineering (CSSE). Johns Hopkins University (JHU); 2020. at https://coronavirus.jhu. edu/map.html (accessed: 29th June 2020).

21. Neumann-Böhme, S., Varghese, N.E., Sabat, I., Barros, P.P., Brouwer, W., van Exel J. (2020) Once we have it, will we use it? A European survey on willingness to be vaccinated against COVID-19. Eur J Heal Econ (Internet). 2020 Sep 26;21(7):977-82. Available from: https://doi. org/10.1007/s10198-020-01208-6 


\section{ČIMBENICI KOJI PREDVIĐAJU PRIHVAĆANJE CJEPIVA PROTIV BOLESTI COVID-19 U ZAPADNOJ AFRICI}

1 Adeleke O.R.

1 Adegboro J.S.

1 Olofintuyi 0.0.

1 Ayenigbara I.O.

1 Aina S.I.

1 Fadero E.O.

1 Oluwadare R.S.

1 Olaseyo T.

1 Department of Human Kinetics and Health Education, Adekunle Ajasin University, Akungba-Akoko

\section{Sažetak}

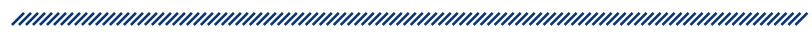

Pozadina: Cilj ove studije bio je ispitati čimbenike koji predviđaju prihvaćanje cjepiva protiv bolesti COVID-19 u zapadnoj Africi, s naglaskom na Nigeriju. Postavljene su četiri hipoteze.

Metode: $U$ ovoj studiji primijenjen je dizajn deskriptivne metode. Uzorak se sastojao od 32224 ispitanika, od kojih su svi građani Nigerije. Za istraživanje je primijenjena tehnika višefaznog uzorkovanja koja uključuje kvantitativne podatke. Kao instrument za prikupljanje podataka primijenjen je upitnik. Podaci prikupljeni za ovu studiju analizirani su primjenom deskriptivne i inferencijalne statistike (t-test i ANOVA).

Rezultati: Nalazi ove studije otkrili su da postoji značajna razlika u prihvaćanju cjepiva protiv bolesti $\mathrm{CO}$ VID-19 na temelju dobi: $F(9,32$ 214 $)=812114, \mathrm{P}<0,05$, $\eta 2=0,1849$; na temelju spolnih razlika: $\mathrm{t}=\left(\begin{array}{ll}32 & 222\end{array}\right)$ $=-21808, \mathrm{P}<0,05$; na temelju religije: $\mathrm{t}=(32222)=$ $-75228, \mathrm{P}<0,05$; te na temelju prihoda: $\mathrm{F}(4,32219)=$ $740394, P<0,05, \eta 2=0,084$.

Zaključak: Nalazi ove studije pokazuju da postoji značajan odnos između dobi, spola, vjere, prihoda i prihvaćanja cjepiva protiv bolesti COVID-19 u Nigeriji. Nalazi dalje pokazuju da muškarci više oklijevaju u pogledu cjepiva od žena; starije osobe lakše prihvaćaju cijepljenje; vjerojatnije je da će kršćani prihvatiti cjepiva protiv bolesti COVID-19 nego ljudi drugih vjeroispovijesti. Stoga se preporučuje da vjerski vođe budu dobro obrazovani o zdravstvenim prednostima cijepljenja protiv bolesti COVID-19 te da vlada uloži više napora u poboljšanje gospodarstva zemlje kako bi se mogli poboljšati individualni prihodi.

Ključne riječi: prihvaćanje, COVID-19, pandemija, čimbenici predviđanja, cijepljenje 